\title{
NOVÉ MOŽNOSTI STANOVENÍ ODOLNOSTI CEMENTOVÝCH KOMPOZITŮ PROTI ABRAZI
}

\author{
NEW POSSIBILITIES OF DETERMINING OF CEMENT COMPOSITES TO \\ ABRASION RESISTANCE
}

Ondřej Pikna ${ }^{*}, 1$, Rudolf Hela ${ }^{1}$, Martin Ťažký1 ${ }^{1}$ Klára Kř́̌̌̌ová ${ }^{1}$

*167308@vutbr.cz

${ }^{1}$ Vysoké učení technické v Brně, Fakulta stavební, Ústav technologie stavebních hmot a dílců, Veveří 331/95, 602 00 Brno

\begin{abstract}
Abstrakt
Nové možnosti zkoušení odolnosti povrchů cementových kompozitů zahrnuje i působení abraze rychle proudící vody. V textu jsou popsány některé způsoby narušení povrchů působením abraze na různých typech konstrukcí, přičemž hlavní zřetel je brán na abrazi povrchů vyvolanou rychle proudící vodou s unášenými pevnými částicemi. V druhé části příspěvku je popsán experiment, při kterém byly testovány cementové kompozity s využitím nové metody pomocí ultrazvukové kavitace, jež simuluje abrazivní účinky rychle proudící vody.
\end{abstract}

\section{Klíčová slova}

Mechanická abraze, abraze rychle proudící vodou, př́íměsi

\begin{abstract}
The new possibilities of testing of resistance of surfaces of cement composites includes action of fast-water abrasion. Several types of surface damage caused by fast-flowing water are described on different type of structures. The focus is on abrasion of surfaces caused by fast flowing water carrying solid particles. The second part describes an experiment in which cement composites are tested using a new ultrasonic cavitation method, which simulates the abrasive effects of fast flowing water.
\end{abstract}

Key words

Mechanical abrasion, fast-flowing water abrasion, mineral additives

\section{1 ÚVOD}

\section{Vliv abraze na degradaci materiálu}

Abraze je nejčastěji principiálně spojována s působením určitého média, které způsobuje degradaci povrchu materiálu. Samotným zdrojem působení mohou být bud' pevné částice, jež narušují materiál př́mým kontaktem s povrchem, nebo kapaliny (často obsahující abrazivní pevné částice) rychle proudící po povrchu materiálu. V obou př́ípadech dochází k narušení části povrchové vrstvy (často i k narušení cementové matrice s uvolněním kameniva z matrice), čímž se povrch stává náchylnějším na všechny druhy degradace počínaje působením mrazu, CHRL či vnikáním agresivních plynných, pevných nebo kapalných látek, které narušují cementový kompozit. Proto je působení abraze bráno hlavně jako katalyzátor pro ostatní druhy degradace [1].

\section{LITERÁRNÍ PŘEHLED}

\section{Typy abraze}

\section{Mechanická abraze}

Mechanická abraze je nejčastěji popisována jako narušení povrchové vrstvy cementového kompozitu (betonu) vlivem brusného média. 
Tento způsob abraze bývá typický pro větší dilatační celky betonových ploch, jako jsou cementobetonové kryty vozovek, letištní plochy, průmyslové betonové podlahy či parkovací plochy. V těchto př́ípadech bývá konstrukce obrušována nejčastěji drobnými pevnými částicemi v souvislosti s provozem vozidel, popř. manipulační techniky $[2]$.

\section{Abraze způsobená pomocí rychle proudící vody s pevnými částicemi}

Diametrálně jiné je působení rychle proudící vody často s unášenými abrazivními pevnými částicemi, které je typické pro namáhané části konstrukcí vodních děl nebo kanalizačních systémů. Za určitých podmínek může být proudění kapalin doprovázeno i procesem kavitace.

Obecné podmínky vzniku kavitačních dutin jsou dány snížením tlaku na hodnotu tlaku nasycených par kapaliny při dané teplotě. Při těchto podmínkách se začnou tvořit dutiny vyplněné parami kapaliny (bubliny). Tyto bubliny v místech s vyšším tlakem již nedokážou absorbovat energii a dochází tak $\mathrm{k}$ jejich zhroucení, tedy kavitaci, která povrch betonu bodově naruší. Zmiňovaný jev bývá doprovázen velmi vysokými teplotami a tlaky (až 2000 bar) a urychlením proudění kapaliny (až $280 \mathrm{~m} / \mathrm{s}$ ) [3-4].

\section{Možné metody stanovení abrazivní odolnosti proti účinkům rychle proudící kapaliny}

\section{Metody využívající vodní paprsek}

Jednou z metod, která se jeví jako vhodná pro zjištění relativní odolnosti proti abrazi vodních děl, je využití vysokorychlostního vodního paprsku. Při této metodě je abraze simulována pomocí tzv. suspendovaných zátěží, které jsou vyvíjeny tryskovým čerpadlem vytvářejícím proud vody o tlaku až 6500 bar. Jako brusné médium lze využít i napřr. suspenzi písku v koncentraci od 20 do $50 \mathrm{~kg} / \mathrm{m}^{3}$ vody. Při vysokých rychlostech (cca $20 \mathrm{~m} / \mathrm{s}$ ) dochází k pronikavé abrazi exponovaného povrchu. Bylo zjištěno, že kromě požadované rychlosti proudění je důležitým parametrem i úhel dopadu vysokorychlostního vodního paprsku. Vyhodnocení této zkoušky bývá nejčastěji založeno na úbytku objemu vzorku, popř. na rychlosti ubývání objemu (erozi) vzorku [8].

\section{Abrazivní metoda „pod vodou“ dle ASTM C1138M-19}

Tato zkušební metoda je navržena tak, aby simulovala abrazivní působení částic unášených vodou. V principu dochází k vytvoření proudění pomocí rotující lopatky o rychlosti 1200 ot/min. Při vyvolaném proudění vody dochází k vynášení ocelových kuliček a následné abrazi zkoušeného povrchu. Rychlost je navržena tak, aby nedocházelo k vynášení ocelových kuliček př́liš vysoko, ale aby docházelo pouze $\mathrm{k}$ otěru testovaného povrchu, což však může limitovat simulaci rychle proudící vody s částicemi.

Standardní doba zkoušení se skládá z šesti intervalů v délce 12 hod., tedy celkem 72 hod. Po zkoušce se vypočte úbytek objemu zkušebního betonového válce o Ø $300 \mathrm{~mm}$ a výšce $100 \mathrm{~mm}$. Tento typ zkoušky je vhodný zejména pro betonové konstrukce vodních děl typu vývar, skluz apod. Pohled na zkušební aparaturu lze vidět na Obr. $1[9,13]$.
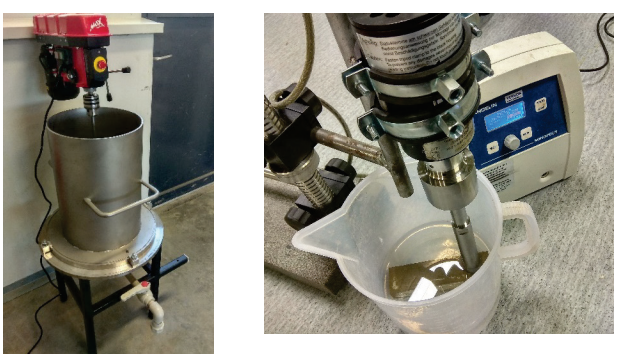

Obr. 1 Zařízení pro abrazivní metodu dle ASTM C1138M-19 a testovací aparatura Ultrazvuku [13].

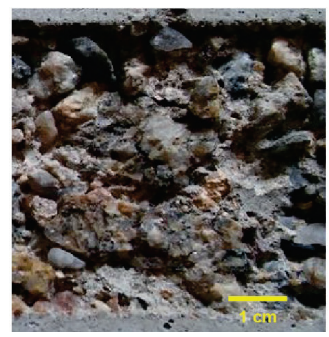

Obr. 2 Vzorek betonu po působení vodního paprsku [7].

\section{Metoda dle ASTM G32-16}

Tato metoda je založena na principu ultrazvukové kavitace, kdy za předpokladu, že tahová pevnost kapaliny závisí na frekvenci ultrazvukového pole, je možné využít nízkofrekvenčních vln. Po dosažení určité energie dochází ke vzniku podobného efektu jako u kavitace vznikající u proudících kapalin [10]. 
Americká norma ASTM slouží především k testování lopatek turbín, konstrukčních částí čerpadel a ventilů u vodních elektráren či lodních šroubů. Jelikož je u těchto prvků předpokládána vyšší abrazivní odolnost, tak může být tato metoda vhodná i pro zkoumání abrazivní odolnosti cementových kompozitů.

\section{METODIKA A VÝSLEDKY}

Experimentální část vychází z poznatků metody dle ASTM G32-16 a zabývá se vhodným nalezením metodiky. Pro simulaci abrazivních účinků rychle proudící vody byla zvolena metoda s využitím ultrazvukového generátoru Sonopuls od firmy Bandelin, osazeného kavitační sondou o Ø $25 \mathrm{~mm}$. Důvodem zvolení této metody byla možnost simulace efektů abraze pomocí rychle proudící vody, jež lze dle některých odborných studií dosáhnout právě pomocí zmíněného ultrazvukového generátoru [4]. Nejúčinnějších parametrů ultrazvuku bylo dosaženo při amplitudě $80 \%$ v čase 5 min, při střídání impulzů 5 s působení a $5 \mathrm{~s}$ pauzy. Na každém vzorku byla v několika bodech stanovena hloubka narušení cementového kompozitu pomocí mechanického dilatometru.

Pro experiment bylo navrženo pět receptur cementových past (Tab. 1) s využitím portlandského cementu CEM I 42,5 R - referenční (REF) a čtyři varianty s částečnou náhradou cementu s aktuálně používanými aktivními př́měsemi - mikromletým vápencem (VÁP), granulovanou velmi jemně mletou vysokopecní struskou (STR), vysokoteplotním černouhelným popílkem (POP) a mikrosilikou (MIKR). Všechny receptury byly navrženy s konstantní konzistencí rozlitím pomocí Hagermannova kužele a strásacího stolku 200 až 210 mm dle ČSN EN 1015-3 [11].

Tab. 1 Receptury testovaných cementových past.

\begin{tabular}{ccccccc}
\hline Receptura & $\begin{array}{c}\text { Vodní } \\
\text { součinitel [-] }\end{array}$ & $\begin{array}{c}\text { CEM I } \\
\mathbf{4 2 , 5} \mathbf{R} \\
{[\%]}\end{array}$ & $\begin{array}{c}\text { Vápenec } \\
{[\%]}\end{array}$ & $\begin{array}{c}\text { Vysokopecní } \\
\text { struska [\%] }\end{array}$ & $\begin{array}{c}\text { Vysokoteplotní } \\
\text { popílek [\%] }\end{array}$ & $\begin{array}{c}\text { Mikrosilika } \\
{[\%]}\end{array}$ \\
\hline REF & 0,325 & 100 & - & - & - & - \\
VÁP & 0,318 & 80 & 20 & - & - & - \\
STR & 0,333 & 70 & - & 30 & - & - \\
POP & 0,335 & 75 & - & - & 25 & 9 \\
MIKR & 0,350 & 91 & - & - & - & - \\
\hline
\end{tabular}

\section{Vyhodnocení metody ultrazvukové kavitace}

Mezi recepturami lze v jednotlivých časových intervalech sledovat rozdíly jak v pevnostních charakteristikách, tak i v odolnosti proti abrazi. Podle vývoje pevnostních charakteristik v čase lze předpokládat, že receptura REF, popř. STR, bude vykazovat vyšší odolnost vůči abrazi. Avšak již v raném stáří vzorků po dvou dnech zrání jsou patrné menší defekty způsobené abrazí kavitací u receptur s využitím pucolánových příměsí (vysokoteplotního popílku i křemičitých úletů) s přibližnou hodnotou hloubky 1,63 mm. Tento výsledek by mohl naznačovat určitou spojitost mezi použitými pucolánovými př́měsemi a odolností cementových kompozitů proti abrazi kavitací. Tento trend lze pozorovat i po následujících sedmi dnech zrání, kdy receptury REF, VÁP a STR vykazují stále stejnou odolnost (hloubku narušení) cca $2,03 \mathrm{~mm}$, zatímco receptura s vysokoteplotním popílkem (POP) dosahuje hodnoty pouze $1,39 \mathrm{~mm}$. U receptury MIKR lze vidět dokonce hodnotu hloubky narušení kavitací pouze $0,34 \mathrm{~mm}$, což může poukazovat na vhodnost této příměsi pro získání lepší abrazivzdornosti.

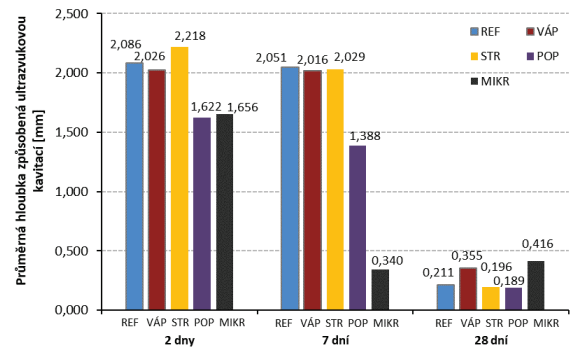

Obr. 3 Stanovení abrazivní odolnosti pomocí ultrazvuku. 
Důvodem odlišné odolnosti proti abrazi s použitím aktivních příměsí, může být vznik homogennější struktury cementového kamene vlivem využití širšího spektra velikostí částic či výraznější podíl jemných CSH gelů. Po 28 dnech (viz Obr. 3) se u všech receptur ukázalo, že je cementový kámen vlivem delšího zrání odolnější natolik, že jsou hodnoty hloubky abraze kavitací téměř o jeden číselný ráa nižší než po sedmi dnech. Na snímcích z mikroskopu (Obr. 4) si lze všimnout, že v případě receptury REF je povrch méně kompaktní a po účincích kavitace je značně bodově narušen. Naopak u receptury MIKR (Obr. 5) je po účincích kavitace vidět kompaktnější a homogennější povrch materiálu a rovněž rovnoměrné rozložení účinků kavitace s menší celkovou hloubkou narušení. To může být důsledek výrazně homogennější, kompaktní struktury matrice. Tyto snímky podporují teorii, že velmi jemná zrna mikrosiliky vytvářejí odolnější cementový kámen.

Účinky kavitace jsou názorně zobrazeny z pohledu 3D vizualizace, kde u receptury REF lze pozorovat více míst s nerovnoměrnými prohlubněmi. Naproti tomu snímky receptury POP po sedmi dnech zrání a účincích kavitace vypadají z pohledu textury hrubší a více narušené (Obr. 6). I z pohledu 3D vizualizace receptura POP vykazuje značně různorodé dutiny po účincích kavitace, zatímco hodnoty celkové hloubky narušení jsou po sedmi dnech zrání relativně nízké $(1,388 \mathrm{~mm})$. Vysvětlením může být, že při působení kavitace může docházet k ,vylupování“ celých kulových nezreagovaných zrn popílku, a tak struktura povrchu působí narušeně, i když je celková hloubka narušení nízká.
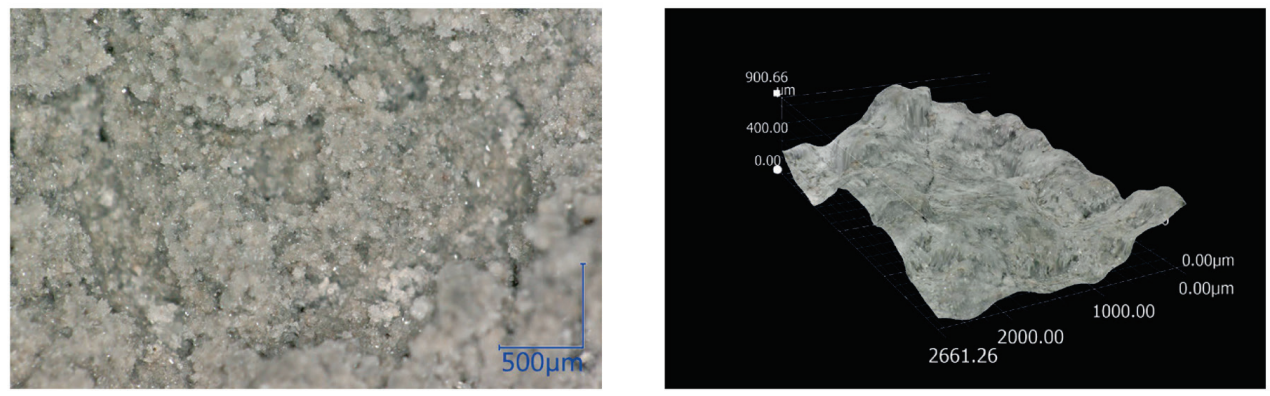

Obr. 4 Receptura REF po sedmi dnech UZ kavitace (zvětšeno 100×) zleva: snímek povrchu a 3D snímek.
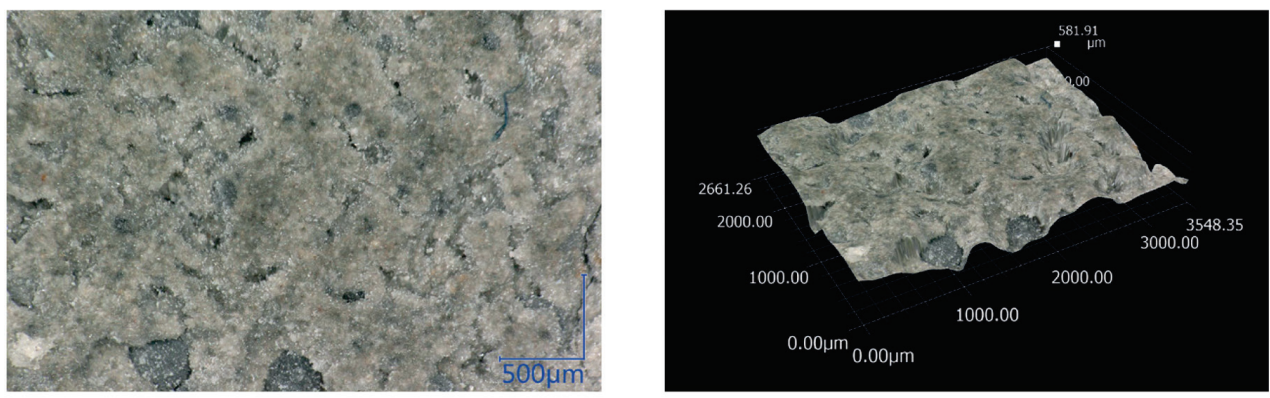

Obr. 5 Receptura MIKR po sedmi dnech UZ kavitace (zvětšeno 100×) zleva: snímek povrchu a 3D snímek.
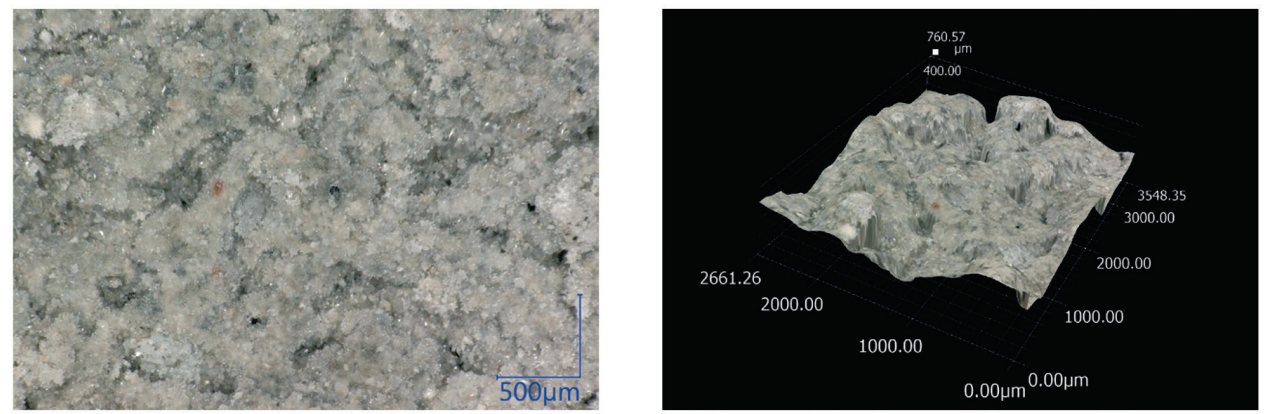

Obr. 6 Receptura POP po sedmi dnech UZ kavitace (zvětšeno 100×) zleva: snímek povrchu a 3D snímek. 


\section{Zkoušky na cementových maltách}

Dále byly namíchány normové cementové malty dle ČSN EN 196-1 s identickým složením odpovídajícím pojivovému zastoupení v Tab. 1. Na těchto maltách byly provedeny některé fyzikálně-mechanické zkoušky pro objasnění vlivu použitých príměsí a pochopení výsledků z měření abrazivní odolnosti [12]. Byly vyrobeny zkušební trámečky o rozměrech $40 \times 40 \times 160 \mathrm{~mm}$, na kterých byly stanoveny pevnosti v tahu za ohybu a pevnosti v tlaku ve stáří 2, 7, 28 a 90 dní. Na zlomcích trámečků bylo provedeno také stanovení nasákavosti.

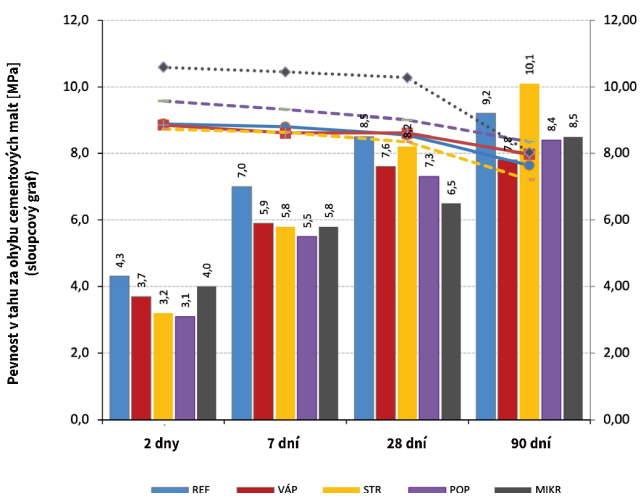

Obr. 7 Stanovení pevnosti v tahu za ohybu cementových malt a jejich nasákavost.

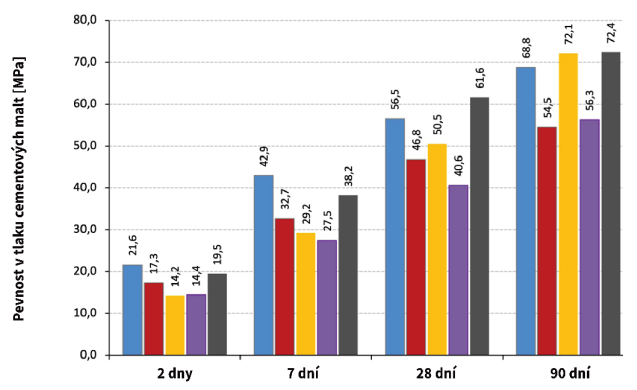

Obr. 8 Stanovení pevnosti v tlaku cementových malt.

Při vyhodnocení zkoušky nasákavosti (výsledky v grafu na Obr. 7) lze pozorovat, že u všech receptur cementových malt došlo ke snížení nasákavosti v intervalech měření po 2, 7, 28 i 90 dnech. To je způsobováno postupným zahušt’ováním struktury matrice cementového kompozitu.

Tyto výsledky částečně korelují s výsledky zkoušek pevnosti v tahu za ohybu. Nejvyšší pevnosti v tahu za ohybu v intervalu od 2 (4,3 $\mathrm{MPa})$ do 28 dní $(8,5 \mathrm{MPa})$ dosahovala receptura REF. Po sedmi dnech byly hodnoty pevností v tahu za ohybu u receptur s náhradou příměsemi (VÁP, STR, POP i MIKR) velmi podobné, cca 5,7 MPa. Př́nos aktivních příměsí se výrazněji projevuje až po 28 dnech hydratace, kdy receptura STR dosahuje téměř srovnatelných hodnot $(8,2 \mathrm{MPa})$ jako receptura REF $(8,5 \mathrm{MPa})$ a po 90 dnech dokonce vyšších hodnot pevností (10,1 MPa) než REF (9,2 MPa).

Pokud porovnáme výsledky stanovení abrazivní odolnosti pomocí ultrazvukové kavitace (Obr. 3) a pevnosti v tahu za ohybu (Obr. 7), lze pozorovat mezi některými recepturami určitou nelogičnost (vycházíme-li z předpokladu, že vyšší pevnost bude znamenat i vyšší odolnost proti abrazi). Např. receptury REF (4,3 MPa) a VÁP $(3,7 \mathrm{MPa})$ dosahují ve stáŕi dvou dnů vyšších hodnot pevností v tahu za ohybu, zatímco hodnoty hloubky způsobené ultrazvukovou kavitací jsou u těchto receptur nejvyšší ( $\mathrm{REF}=2,086 \mathrm{~mm}$ a VÁP $=2,026 \mathrm{~mm})$, resp. odolnost vůči abrazi kavitací je nejnižší.

Toto tvrzení neplatí ovšem v př́ípadě receptury MIKR, která po dvou dnech zrání dosahuje vyšších hodnot pevností v tahu za ohybu (4,0 MPa) a zároveň nejvyšší odolnosti vůči abrazi kavitací.

Výsledky naznačují, že v raném stáří by abrazi způsobené rychle proudící vodou mohly lépe odolávat právě receptury s využitím velmi jemných aktivních př́měsí. Může to být dáno kvalitou vzniklého povrchu, který je homogennější a hladší bez výrazně vyčnívajících větších zrn plniva.

\section{ZÁVĚR}

Ultrazvuková metoda se sondou od firmy Bandelin typu VS 200 T a použité parametry ultrazvuku se ukázaly jako efektivní pro pevnosti v tlaku do cca $40 \mathrm{MPa}$. Pro pevnosti dosažené ve stáří 28 dnů, kdy se hodnoty posunuly na cca $50 \mathrm{MPa}$, se účinnost působení těchto parametrů ultrazvuku a typu sondy snižovala a rozdíly v destrukci se smazávaly. Nabízí se zde prostor pro ověření jiných parametrů ultrazvukové metody, jež by zvýšily účinnost kavitace. Z dosažených pevnostních parametrů cementových malt v jednotlivých časových intervalech vyplývá, že zde nemusí být př́má souvislost s odolností proti abrazi kavitací. Ukázalo se, že výrazný vliv na odolnost proti abrazi způsobené rychle proudící vodou a kavitací má kvalita a homogenita mikropovrchu. Přínosné se pro zlepšení této odolnosti jeví využivání jemnozrnných aktivních příměsí, především mikrosiliky a kvalitních vysokoteplotních popílků. 
Použitá ultrazvuková metoda může být využitelná pro simulaci účinků abraze vyvolané rychle tekoucí vodou. Vhodné může být také spojení zmíněné metody s metodou dle ASTM C1138M-19, kterou začínáme rovněž testovat (Obr. 1) [13].

V současnosti se rekonstruje několik vodních děl, kde jsou bezpečnostní přepady, skluzy a vývary tomuto typu abraze vystaveny. Receptury betonů jsou navrhovány v souladu s ustanoveními ČSN 73 2404/Z1 př́lohy F, která je sice nazvána informativní, ale Tab. F2 má název mezní hodnoty, což v praxi vyvolává dojem, že je nutné se těmito hodnotami řídit. Bez adekvátních zkoušek, které ověří působení různých typů abraze, není tento př́stup k navrhování extrémně namáhaných betonů technicky správný. Popsané metody zkoušení dávají solidní informace o chování povrchů vystavených rychle proudící vodě a bylo by možné na nich začít budovat jednotné testovací metody [6].

\section{Poděkování}

Příspěvek byl vytvořen v rámci řešení projektu: VUT specifického výzkumu FAST-S-21-7393: Studium lehkých betonů za vysoké teploty.

\section{Použité zdroje}

[1] BODNÁROVÁ, L., ŤAŽKÝ, M., ŤAŽKÁ, L., HELA, R., PIKNA, O., SITEK, L. Abrasive Wear Resistance of Concrete in Connection with the Use of Crushed and Mined Aggregate, Active and Non-Active Mineral Additives, and the Use of Fibers in Concrete. Sustainability [online]. Basel, Switzerland: MDPI, 2020. 27. 11. 2020, Vol. 12, No. 23. [cit. 9. 11. 2021]. ISSN 2071-1050

[2] GARCÍA, A., CASTRO-FRESNO, D., POLANCO, J. A., THOMAS, C. Abrasive wear evolution in concrete pavements. Road Materials and Pavement Design [online]. Oxfordshire, Great Britain: Taylor \& Francis, 2012, Vol. 13, No. 3, pp. 534-548. [cit. 9. 11. 2021]. ISSN 2164-7402. DOI:10.1080/14680629.2012.694094

[3] SUSLICK, K. S., Sonochemistry. Kirk-Othmer Encyclodpedia of Chemical Technology [online]. 4. ed. New York: John Wiley, 1998, pp. 516-541. [cit. 9. 11. 2021]. ISBN 0-471-52696-7. Dostupné z: suslick. scs.illinois.edu/documents/koencyc1998516.pdf

[4] PETERS, S. The Influence of Power Ultrasound on Setting and Strength Development of Cement Suspensions. Weimar, 2016. Dizertační práce. Bauhaus-University Weimar. Vedoucí práce Prof. Dr.Ing. Horst-Michael Ludwig, Prof. Dr. H. F. Reinhard Trettin, Prof. Dr. ir. H. J. H. (Jos) Brouwers.F

[5] GIRIDHAR, M, MADAVI, M., ANIRUDH, R., GOUD, E. R. Analysis of Pressures on Nagarjuna Sagar Spillway: Cavitation damage on spillway profile of Nagarjunasagar Dam. ecronicon.com [online]. Ecronicon, 2014. [cit. 9. 11. 2021]. Dostupné z: ecronicon.com/ecag/agriculture-ECAG-01-00004.php

[6] ČSN P 73 2404/Z1. Beton - Specifikace, vlastnosti, výroba a shoda - Doplňující informace. Praha: ÚNMZ, 2018

[7] BODNÁROVÁ, L., HELA, R., WOLF, I., VÁLEK, J. High-speed water jet (HSWJ) for concrete surface treatment - evaluation of concrete surface properties after blasting using HSWJ technology. Technical Gazette [online]. Slavonski Brod, Croatia, 2012, Vol. 19, No. 2, pp. 361-366. [cit. 9. 11. 2021]. ISSN 1330-3651. Dostupné z: hrcak.srce.hr/83912

[8] LIU, H. T., SCHUBERT, E. Micro Abrasive-Waterjet Technology. Micromachining Techniques for Fabrication of Micro and Nano Structures [online]. Rijeka, Croatia: In-Tech, 2012, pp. 205-234 [cit. 6. 3. 2021]. ISBN 978-953-307-906-6. DOI: 10.5772/30409.

[9] KUMAR, Ramesh a U.K. SHARMA. Abrasion resistance of concrete containing marginal aggregates. Construction and Building Materials [online]. Amsterdam, Netherland: Elsevier, 2014, Vol. 66, pp. 712-722. [cit. 9. 11. 2021]. ISSN 0950-0618. DOI:10.1016/j.conbuildmat.2014.05.084

[10] ASTM G32-16. Standard Test Method for Cavitation Erosion Using Vibratory Apparatus. West Conshohocken, USA: ASTM International, 2016.

[11] ČSN EN 1015-3. Zkušební metody malt pro zdivo - Část 3: Stanovení konzistence čerstvé malty (s použitím střásacího stolku). Praha: ÚNMZ, 2000.

[12] ČSN EN 196-1. Metody zkoušení cementu - Č́st 1: Stanovení pevnosti. Praha: ÚNMZ, 2016.

[13] ASTM C1138M-19. Standard Test Method for Abrasion Resistance of Concrete (Underwater Method). West Conshohocken, USA: ASTM International, 2019 